\title{
HIKING TRAILS AS THE TOURIST POTENTIAL OF SZCZYTNA CITY AND MUNICIPALITY
}

\section{ELEONORA GONDA-SOROCZYŃSKA, ${ }^{1}$ IGA WIKTORIA MICHALAK ${ }^{2}$}

\author{
Wrocław University of Environmental and Life Sciences, POLAND \\ ${ }^{1}$ e-mail: eleonora.gonda-soroczynska@up.wroc.pl \\ 2 e-mail: michalak.iga@gmail.com
}

KEYWORDS ABSTRACT
Szczytna, tourism, tourist potential, hiking trails, tourist management

The presented research highlights the tourist potential of Szczytna city and municipality located in Lower Silesia Province, close to such popular spa and health resorts as Polanica-Zdrój, DusznikiZdrój and Kudowa-Zdrój. Special attention was devoted to hiking trails, identified as the factors which attract and will continue to attract both tourists and the potential investors. Szczytna city and municipality offer few architectural relics of the past, historic elements of small architecture, interesting forms of nature protection, e.g.: Stołowe Mountains National Park [Table Mountains National Park], Peatbog in the vicinity of Zieleniec (nature reserve), Bystrzyckie and Orlickie Mountains (protected landscape area), Nature 2000 area, 8 nature monuments. All the above mentioned elements can be admired while hiking along tourist trails. Currently their length amounts to approx. $115 \mathrm{~km}$ in the area of Szczytna municipality. Within the framework of the conducted research over $70 \mathrm{~km}$ of them were analysed. The length and density of hiking trails implies high attractiveness of the studied area, therefore the places presenting extensive tourist potential were covered by the analysis. The valorisation of hiking trails was based on Wejchert's impression curve method, which allowed their evaluation. On the grounds of its results the sites adequate for new tourist investments were identified.

\section{Introduction}

Szczytna is a small urban-rural municipality located in south-western part of Poland, in Kłodzko County, geographically in the Central Sudetes. Its range covers parts of four topographical units: Stołowe Mountains [Table Mountains] (northern part of the municipality), DusznikiSzczytna Depression (western part of the municipality), Bystrzyckie Mountains (southern part of the municipality) and Kłodzko Valley (eastern part of the municipality) (Staffa, 1996, pp. 236-237). 
The municipality under analysis is divided into three parts: the city area, as well as eastern and western rural areas.

Szczytna is located along the international Wrocław-Prague route, which facilitates and speeds up motorised communication. Additionally, one can use the services of PKS [Polish Car Transport Company] and private transport from Wrocław or Czech private bus service. The regular, although infrequent, PKP [Polish Rail] transport offers connections Kłodzko-Kudowa-ZdrójKłodzko (with a option to change in Kłodzko for other directions). The nearest airport is situated in the Czech Republic in the locality of Letiště Jaromě (approx. $70 \mathrm{~km}$ away). Wrocław airport is located within the distnce of $107 \mathrm{~km}$.

The area of Szczytna city and municipality is characterized by the following nature protection forms: Stołowe Mountains National Park, Peatbog in the vicinity of Zieleniec (nature reserve), Bystrzyckie and Orlickie Mountains (protected landscape area), Nature 2000 area (Bystrzyca Łomnicka Valley, Stołowe Mountains, Piekielna Valley [Devilish Valley] near Polanica-Zdrój, Grodczyn and Homole near Duszniki-Zdrój), 2 nature monuments in the city of Szczytna and 6 nature monuments in the area of Szczytna municipality (http://crfop.gdos.gov.pl/CRFOP/search. jsf, 18.12.2015; Register of nature monument in Lower Silesia Province). The municipality offers numerous historical monuments and is known for holding a wide range of cultural and sport events. It is situated close to the popular spa and health resorts: Polanica-Zdrój, Duszniki-Zdrój, Kudowa-Zdrój which, along with its natural advantages, guarantee the continuous inflow of tourists (Gonda-Soroczyńska, 2014, pp. 68-75). The close vicinity of Stołowe Mountains National Park and other nature protection forms has a positive effect on its attractiveness. The close proximity of the Czech Republic border is also significant (arrivals of many Czech tourists and the organization of trips to the Czech Republic). However, in spite of all the above mentioned advantages Szczytna has not been very popular among tourists so far, therefore new, interesting attractions or sites should be offered, acting as incentives and provoking to see and visit them - vide other tourist centres, e.g. Karpacz (Gonda-Soroczyńska, 2010, pp. 375-384). Taking advantage of tourist potential constitutes the grounds for developing the tourist function, just as it happened in the Silesian town of Ustroń (Petryszyn, Zuzańska-Żyśko, 2008, pp. 133-144).

In the area of Szczytna municipality the total length of PTTK [Polish Tourist and Sightseeing Society] hiking trails amounts to approx. $115 \mathrm{~km}$. Over $70 \mathrm{~km}$ of them were analysed within the framework of the conducted research. The length and density of these trails implies high attractiveness of the analysed area, therefore the sites characterized by an extensive tourist potential were explored. Wejchert's impression curve method was chosen for the purpose of tourist trails' valorisation. In the course of field research the inventory of selected trail elements was additionally prepared.

\section{Research purpose and scope}

The primary purpose of the conducted research was to identify the tourist potential of Szczytna city and municipality, placing particular emphasis on hiking trails. The basic data about Szczytna 
city and municipality were collected and the analyses of tourist facilities offered by the city were conducted. The inventory and valorisation of selected hiking trails using Wejchert's impression curve method was performed. Based on the research results, the proposals of new tourist investments' location in the sites characterised by the highest tourist potential' were presented. The provided recommendations took into account the course and attractiveness of the discussed hiking trails.

\section{Historic monuments as the tourist potential of Szczytna city and municipality}

Szczytna city and municipality cannot offer many and high quality historic advantages. Among the most important relics of the past the following can be listed: the Church of St. John the Baptist (Baroque construction from 1725 in the centre of Szczytna, with the sarcophagus tomb of Zygfryd von Hochberg the canon from Szczytna, with the altars by Michael Klahr the Elder, with the tombstone in Polish from 1850 built into the wall of the church - the traces of Polish origins on this land); the cemetery next to the above mentioned church with the first cemetery chapel from 1579; Baroque vicarage by the church, erected in the years 1721-1724 with a mansard roof covered with slate; "Leśna" neo-Gothic castle from 1838 at Szczytnik, the residence of Hochberg family (589 m a.s.1.), made from sandstone, with four towers, currently a Nursing Home; a chapel at "Leśna" castle, in one of the four-sided towers, $12 \mathrm{~m}$ long, $7 \mathrm{~m}$ wide and $8 \mathrm{~m}$ high with tombs of the later castle owners; Way of the Cross in the wood located to the north-east of "Leśna" castle with the Stations of the Cross carved in the sandstone rock; neoclassical palace (the building with a colonnade, the seat of the old owners of Szczytna mansion, previously a primary school, currently abandoned); the building of the former railway station constructed in the years 1890-1895, presently used as an apartment building; the Church of St. Ann in Batorów from 1456 (on the route of yellow and green hiking trails, made of stone, inside three candlesticks - candelabras made of crystal glass, probably manufactured in Szczytna glass factory); Calvary near the Church of St. Ann in Batorów (the Passion along the difficult, mountainous terrain, constructed around the $19^{\text {th }}$ century and made of stone blocks with images on tinplate, presenting not very clear drawings (Wydawnictwo Towarzystwa..., 1985; Pilch, 1978, p. 339; Staffa, 1996, pp. 238-241). Attention should also be paid to the components of small architecture e.g.: the fragment of the original $16^{\text {th }}$ century pillory in front of the Church of St. John the Baptist; the monument of St. Jan Nepomucen from 1723 upon Kamienny Potok [Stony Creek] river; the second figure of St. Jan Nepomucen from 1723 next to the drawbridge at Szczytnik by "Leśna" castle; two penitential crosses in Batorów.

\section{Research methodology}

The following research methods were used in the course of the conducted studies: observation method as the primary one and intuitive method as the secondary one.

The observation method represents the way of conducting research in the course of which observation plays an important role and the application of which does not result in local environment changes. It is focused on purposeful searching for facts and on a deliberate cognitive activity using 
senses. Observation is based on the inventory and valorisation of hiking trails using Wejchert's impression curve method.

The intuitive method represents analysing concepts, assumptions, problems, projects or other elements of the broadly approached research work. It remains the ever-present and indispensable component of every research method. It is necessary to justify the problem of a working method choice, to identify the assumptions and specify the hypotheses.

The following research questions were adopted in the study: "What modifications should be used in relation to hiking trails in Szczytna city and municipality to make them more attractive than they have been so far?"; "How can the existing hiking trails' potential of Szczytna city and municipality be taken advantage of in order to locate new investments, especially the tourismoriented ones?"

\section{Valorisation using Wejchert's impression curve and inventory}

Hiking trails in Szczytna municipality represent its important tourist asset. The research covered 7 sections of hiking trails, i.e.: [1.] red trail between the hostel Pod Muflonem [Under the Mouflon] and Polanica-Zdrój $(8.5 \mathrm{~km})$; [2.] yellow trail between Karłów and Duszniki-Zdrój (16.5 km); [3.] yellow trail: between Piekielna Góra [Devilish Mountain] and the hostel Pod Muflonem (8.5 km); [4.] blue trail: Wambierzyce-Szczytna section $(10.1 \mathrm{~km})$; [5.] green trail: Szczytna-Karłów trail $(9.5 \mathrm{~km})$; [6.] green trail: between Topieliska near Zieleniec and Kamienna Góra $(8.7$ km); [7.] black trail: between Kamienna Góra and Szczytna $(9.4 \mathrm{~km})$. The analysis covered the total of $71.2 \mathrm{~km}$ of hiking trails out of $115 \mathrm{~km}$ of such trails in the area of Szczytna city and municipality.

Valorisation represents the subjective assessment of a researcher, depending also on many changing external factors (e.g. the weather on the day of measurement and on the days before) (Hopfer, Cymerman, Nowak, 1982, pp. 128-142). Each of the described hiking trail sections was subject to inventory and valorisation on the exact same day. The exception is the section of yellow trail between Piekiełko [Inferno] and the hostel Pod Muflonem, which was divided into two days (the stages Szczytna - hostel Pod Muflonem and Piekiełko - Szczytna). Measurement points were set every 5 minutes along the way. It resulted from the approach that time represents a more precise method of observation and landscape evaluation than distance for a tourist hiking in the mountains. A hiker, when climbing up moves slower than while walking down and thus more attentively observes the landscape, which changes more slowly. The research was conducted between 22.07.2015 and 9.09.2015. It covered: the degree of landscape diversity, the level of devastation, the condition of road infrastructure, the harmony of composition, the abundance of flora and fauna, the acoustic climate, the olfactory flavours, the sense of space (Obidziński, Żelazo, 2011, pp. 109110; Gaworecki, 2003, pp. 123-127; Gordon, 2003, pp. 116-119; Dudzińska, Świerk, Jeleniewska, Urbański, 2014, pp. 79-88; Mordwa, 2009, pp. 89-98).

Wejchert's impression curve method is a graphic method used to present the feeling of a person observing the surrounding landscape in a space-time continuum. Its main purpose was to 
compare the fragments of space and to choose places where investments are either advisable or indispensable.

Points were allocated on the scale from 1 to 10 , where 10 was the best evaluation. The analysed sections were evaluated based on nine components:

- the degree of landscape diversity - the level of a particular measurement section diversification. The more different landscape forms occurred the more interesting they were, the higher note was awarded,

- the level of devastation - the level of natural environment degradation. The lower it was the higher note was given,

- the condition of road infrastructure - the only component which was always evaluated equally for both parties. It resulted from the fact that the evaluation referred to the road followed by the observer, which was in the middle. The easier it was for the observer to move along it the higher note was received,

- the harmony of composition of all existing components - the level of spatial order and aesthetics was evaluated. The more attractive it was the higher not was given,

- the abundance of flora - the evaluation covered the quality and diversity of greenery. The more attractive it was, the higher note was assigned,

- the abundance of fauna - the component which evaluated the presence of animals. The more animals were observed or heard the higher note was received,

- the acoustic climate - the evaluation covered sound stimuli. Bird singing was the particularly desired one. The more positive the feelings were the higher note was awarded,

- the olfactory flavours - the evaluation was based on all olfactory stimuli. The more positive and detectable they were the higher note they received,

- the sense of space - the component which defined the sense of safety in the surrounding space. The larger the landscape walls and openness were the higher note was assigned to it.

Such components as the acoustic climate and olfactory flavours were assessed locally. The evaluation covered the site where the measuring point was placed. All the other components were evaluated on a section basis (apart from point one). The notes given e.g. in the second point refer to the entire section between point one and two. Whenever a particular point is mentioned it refers to the entire measured section.

All the above mentioned components were put together in a table, separately for the right side of the trail and for the left one. Next they were averaged and divided into places highly requiring investments (less than 4 points), requiring investments (from 4 to 6 points) and not requiring investments (more than 6 points). The places highly requiring and requiring investments were described and the examples of actions resulting in their evaluation improvement were recommended.

The results of valorisation, apart from the descriptive part, also provide the charts of Wejchert's impression curves and the graphic part.

\section{Red trail: the section hostel Pod Muflonem - Polanica-Zdrój}

The trail is $11,4 \mathrm{~km}$ long. It starts in Duszniki-Zdrój at the hostel Pod Muflonem and finishes in Polanica-Zdrój at the pedestrian precinct. 


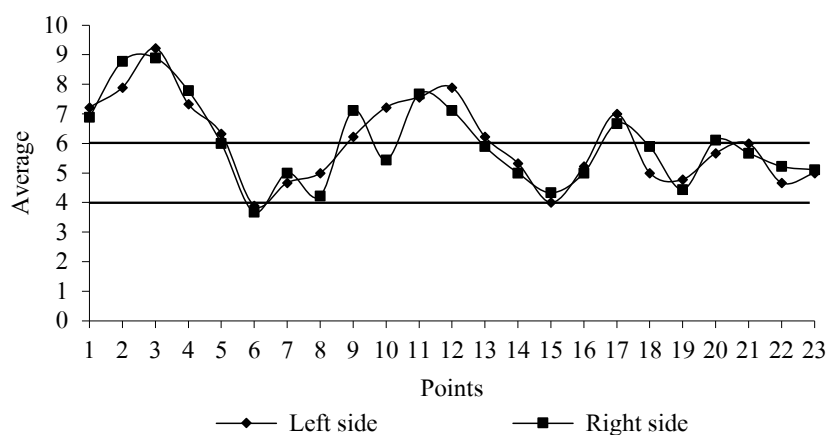

Figure 1. Wejchert's impression curve for the section of red trail between the hostel Pod Muflonem and Polanica-Zdrój

Source: author's compilation.

The course of Wejchert's impression curve is similar for both sides. Only one result, the sixth measurement point placed among trees and bushes is evaluated below 4 points (Figure 1). Having considered the particular components included in the analysed point it was agreed that its low value was mainly due to: the poor condition of road infrastructure (at this place the road is very muddy) and also the sense of space (resulting from the above mentioned surrounding trees and bushes).

Quite many measurement points were included in the range between 4 and 6 points. Among them there are the following points: $7,8,14,15,16,18,19,22,23$, right sides of points 10,13 and 21 and also the left side of point 20.

The analysed red trail was positively evaluated. It is diversified, rich in all the discussed components. If the above mentioned small investments are made, along with an improved promotion, e.g. on Szczytna website, it should be popular among tourists. It must, however, be emphasized that it is a very demanding and difficult trail, therefore adequate for tourists well experienced in mountain hiking. It is not recommended for the elderly or people with kids.

\section{Yellow trail: the section between Karłów and Duszniki-Zdrój}

The first described section of the trail is approx. $15 \mathrm{~km}$ long. It starts at Pod Zbójem [Under the Ruffian] (Karłów; the intersection of yellow and blue trails) and finishes at Ceglana Góra [Brick Mountain] (Duszniki-Zdrój). It is an easier option for starting and finishing the trail.

The course of Wejchert's impression curve is similar for both sides. Additionally, the chart clearly shows that the trail received very high notes (Figure 2). There was only one point which was qualified in the category below four points. It refers to point 13, the low evaluation of which resulted from such components as the level of devastation, the harmony of composition, the abundance of flora and fauna, the olfactory flavours and the sense of space. This section, unfortunately very neglected, remains a part of Skalne Grzyby [Rock Mushrooms] formation. The densely growing coniferous trees, frequently dried out, constitute the landscape on both sides. Therefore, all the above components bring about negative impressions. The suggested action to be taken here is to 
arrange the bedding and take care of the trees. Points in the range of 4-6 include: the left side of 1, 2, 9 points; points 10, 11, 12, 15, 16, 19, 25, 30, 31 and 37.

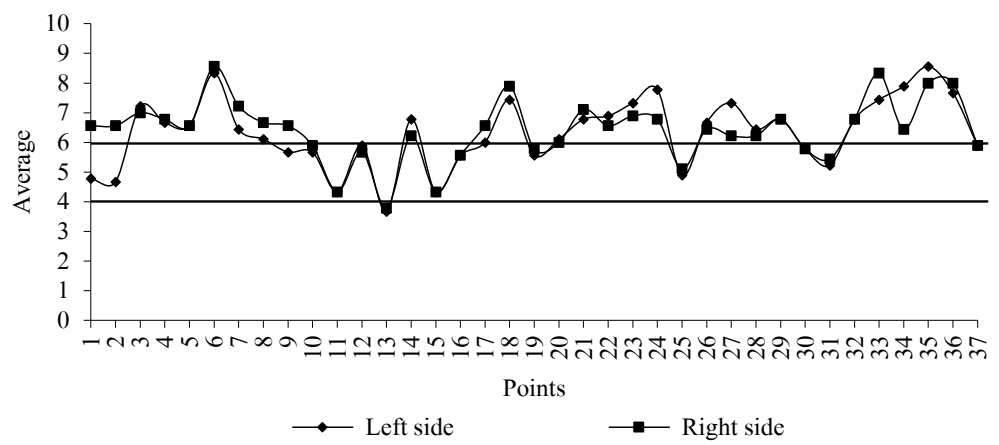

Figure 2. Wejchert's impression curve for the section of yellow trail between Karłów and Duszniki-Zdrój Source: author's compilation.

The analysed yellow trail, along the section between Karłów and Duszniki-Zdrój, represents the third best evaluated trail. Its landscape is highly diversified and rich in many interesting elements of animate and inanimate nature. It also offers picturesque panoramic viewpoints. The trail is popular with tourists, however, only along some of its parts. The promotion of e.g. Skała Józefa [Joseph's Rock] on Szczytna's website seems a good solution. The entire section requires investments, however, it does offer a great potential.

The trail is not too difficult and suitable even for parents with kids or elderly tourists (The Mountain of St. Ann can turn out the only difficulty). Unfortunately, from around 25. point the trail is so neglected that hiking along it remains a true challenge. Until its condition is improved this part is recommended for experienced tourists only.

\section{Yellow trail: between Piekielna Mountain and the hostel Pod Muflonem}

The part of yellow trail between "Piekiełko" and the hostel Pod Muflonem, within the borders of Szczytna municipality is just over $8 \mathrm{~km}$ long.

The course of Wejchert's impression curve is almost identical for both sides. Additionally, just like in case of the above discussed yellow trail section, it is clearly visible that the trail received very high notes (Figure 3). It included only one point which was qualified in the category below 4 points. It refers to point 18 and its low evaluation results from such components as the level of devastation, the composition harmony of all present components, the abundance of flora, the olfactory flavours, the degree of landscape diversity, the abundance of fauna and the sense of space. This section runs through a devastated forest. Its negative evaluation is mainly due to the uncleared branches deep in the forest. The impression of bleak landscape is intensified by the fact that the previous sections were very attractive. The suggested activity in this place is to clear the brunches 
and plant shrubs, e.g. bush berries. Points in the range of 4-6 include: the right side of point 9 as well as points 11 and 19 .

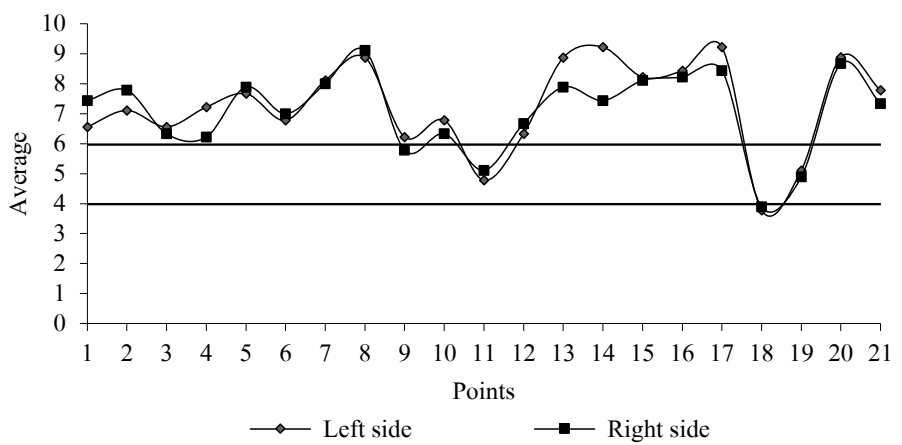

Figure 3. Wejchert's impression curve for the section of yellow trail between Piekielna Mountain and the hostel Pod Muflonem

Source: author's compilation.

The analysed yellow trail along the section between Piekielna Mountain and the hostel Pod Muflonem remains the highest evaluated trail. It is well maintained offering much diversified landscape. It includes valuable elements in terms of nature, history and culture. Moreover, apart from a few difficult places (the part near Leśna castle and the part in front of Pod Muflonem hostel) the trail is quite easy. It is suitable for parents with kids or elderly tourists.

\section{Blue trail: the section Wambierzyce-Polanica-Zdrój}

The trail is $28,1 \mathrm{~km}$ long and runs from Polanica-Zdrój to the carpark at Radkowskie Rocks. The part in Szczytna municipality is almost $9 \mathrm{~km}$ long.

The above presented Wejchert's impression curve illustrates that the left sides were awarded better notes more frequently than the right sides (Figure 4). The entire graph, however, presents a similar course for both sides. It is clearly visible that many values are included in the range between 4 and 6 points, but none of the values was below 4 points. The chart is quite regular with only few extreme points.

Points in the range 4-6 include: the left side of points 1 and 12; points 3, 4, 7, 13, 21; right sides of points $9,14,15,17$ and 18 .

The analysed section of blue trail is quite regular, unvaried and thus relatively monotonous. It practically runs only through the forest and therefore it is recommended for tourists seeking tranquillity and quietness. Skalne Grzyby represent its major attraction. The level of this trail difficulty is low and suitable for all tourists. 


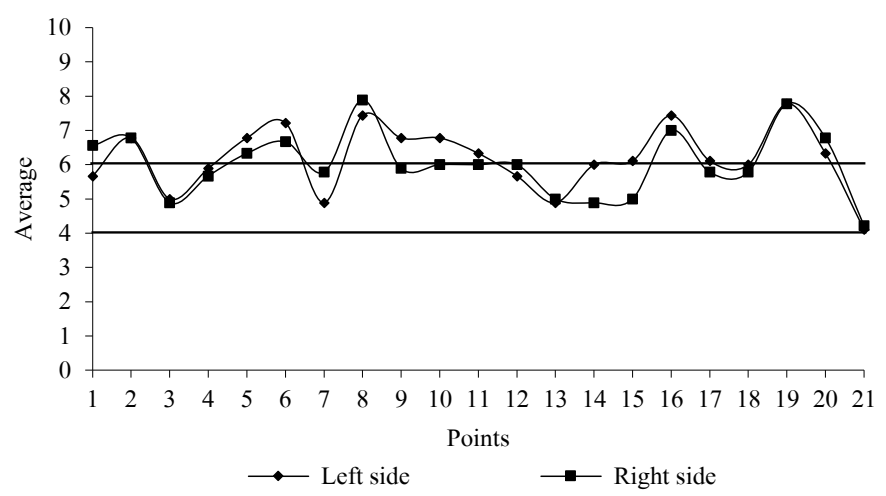

Figure 4. Wejchert's impression curve for the section of blue trail between Wambierzyce and Polanica-Zdrój Source: author's compilation.

\section{Green trail: the section of green trail between Topieliska near Zieleniec and Kamienna Góra}

The green trail is $9 \mathrm{~km}$ long and is easier to cover from Zieleniec side towards Kamienna Góra in Polanica-Zdrój.

Wejchert's impression curve is almost identical in its course for both sides and remains quite regular (Figure 5). It is easily noticeable that the majority of values are included in the range above 6 points. There are no values below 4 points.

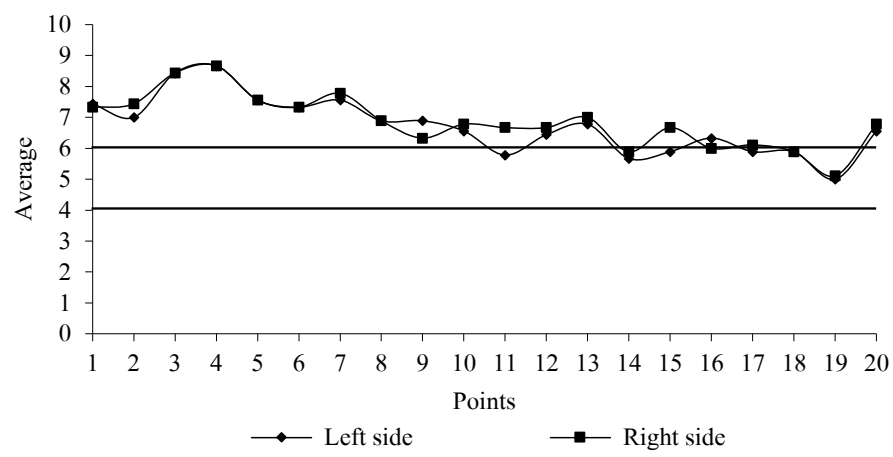

Figure 5. Wejchert's impression curve for the section of green trail between Topieliska near Zieleniec and Kamienna Góra

Source: author's compilation.

Points in the range 4-6 include: the left side of points 11, 15, 17 and points 14, 18, 19. The analysed green trail along the section between Topieliska near Zieleniec and Kamienna Góra represents 
the second best evaluated trail. It is well maintained and equipped with all the components which a tourist may need. It is, in its entire length, easy to cover (the absence of footbridges or their poor condition in the area of Topieliska near Zieleniec can cause some difficulties). In spite of that it is mainly recommended for the elderly tourists or parents with kids. An actively hiking tourist will feel bored while covering it (the exception is Topieliska near Zieleniec which remains a big attraction).

\section{Black trail: the section Kamienna Góra-Szczytna}

It is the most recently marked out, $24 \mathrm{~km}$ long, trail. It leads from Kamienna Góra in PolanicaZdrój to Wambierzyce. Almost the entire trail runs in Szczytna municipality. Its part, subject to inventory and valorisation, starts from the place behind the observation deck on Kamienna Góra and finishes in the centre of Szczytna. The section is approx. $10 \mathrm{~km}$ long. This stage is the easiest to cover from Kamienna Góra to Szczytna.

Wejchert's impression curve is almost identical in its course for both sides of the trail (Figure 6). There are only few places evaluated above 6 points. As many as five points $(6-10)$ and the right side of point 12 received notes below 4 points. Points 6-10 are located in the area of Wolarz Mountain. They received low notes, practically, for each component. Even though the trail has been relatively recently marked out, it is very unattractive along the above mentioned part. Points in the range 4-6 include: points $3,4,5,11,13,14,17,18$ and the left side of point 15 .

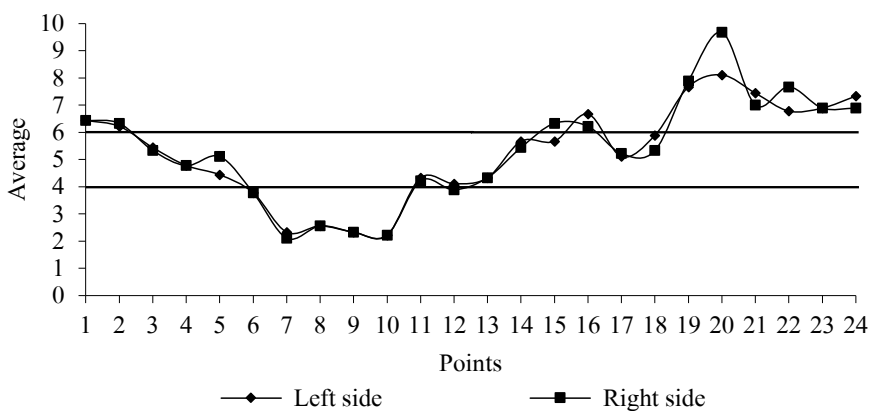

Figure 6. Wejchert's impression curve for the black trail section between Kamienna Góra and Szczytna Source: author's compilation.

The analysed black trail is the worst evaluated one in this section. It is highly neglected and does not offer elements of interest for a tourist. Furthermore, the trail is of a shortcut character, but between points 10 . and 16 . leads tourists, unnecessarily, around the existing road. The low level of forestation and the terrain profile offers the possibility of its shortening. The trail is highly demanding in the area of Wolarz Mountain. It is dedicated to those tourists only who practice active hiking. 


\section{Conclusions}

Szczytna City and Municipality offer quite an extensive tourist potential, still not fully taken advantage of. It consists of e.g. hiking trails which are exceptionally interesting, picturesque and abundant in numerous natural forms, attractive for a tourist. Their large number and diversity of the difficulty level allow tourists representing different age groups and physical fitness to use them. In order to locate interesting and indispensable tourist investments the primary attention should be paid to the yellow trail as the most interesting one of all the analysed trails. It also provides bigger chances for a successful investment. In case of the other trails all the existing inconveniences should be removed and new spots created, so that Szczytna could become attractive for tourists. A hiking trail, approx. 10-15 km long, is missing within the city borders, which could become an educational trail, adjusted for all tourists of different age groups, leading along the most interesting places and terrain attractions (Kurek, 2008, pp. 24-29, 42-44; Gaworecki, 2003, pp. 26-36, 123-127).

For the purposes of the analysed hiking trails' modification the recommendations resulting from the research conducted using Wejchert's impression curve should be adapted. The tourist potential of hiking trails in the entire Szczytna municipality, by means of locating new tourism oriented investments, will soon be adequately taken advantage of through implementing a tourism activation concept. This problem will be discussed in detail in the next publication.

\section{References}

Dudzińska, A., Świerk, D., Jeleniewska, M., Urbański, P. (2014). Perception-Based Valuation of Landscape in the Area around Lake Rusałka in Poznań, Poland, Using Wejchert's Impression Curve Method. Barometr Regionalny, 12 (1), 79-88.

Gaworecki, W.W. (2003). Turystyka. Warszawa: PWE.

Gonda-Soroczyńska, E. (2010). Elementy zagospodarowania turystycznego w Karpaczu. Problemy Ekologii Krajobrazu, XXVI, 375-384.

Gonda-Soroczyńska, E. (2014) Wielofunkcyjność czy jednofunkcyjność? Uzdrowiska w obliczu przemian przestrzennych? Prace Naukowe Uniwersytetu Ekonomicznego we Wrocławiu, 367, 68-75.

Gordon, A. (ed.) (2003). Turystyka w gminie i powiecie (pp. 116-119). Warszawa: Polska Organizacja Turystyczna.

Hopfer, A., Cymerman, R., Nowak, A. (1982). Ocena i waloryzacja gruntów wiejskich (pp. 128-142). Warszawa: Państwowe Wydawnictwo Rolnicze i Leśne.

Kurek, W. (2008). Turystyka. Warszawa: Wydawnictwo Naukowe PWN.

Mordwa, S. (2009). Krzywa wrażeń dla ulicy Piotrkowskiej w Łodzi. Acta Universitatis Lodziensis. Folia Geographica Socio-Oeconomica, 10, 89-98.

Obidziński, A., Żelazo, J. (red.) (2011). Inwentaryzacja i waloryzacja przyrodnicza (pp. 109-110). Warszawa: Szkoła Główna Gospodarstwa Wiejskiego.

Petryszyn, J., Zuzańska-Żyśko, E. (2008). Od funkcji przemysłowej do turystycznej - przykład Ustronia (pp. 133-144). In: I. Jażdżewska (ed.), Funkcja turystyczna miast. XXI Konwersatorium Wiedzy o Mieście. Łódź: UŁ.

Pilch, J. (1978). Leksykon zabytków architektury Dolnego Śląska. Warszawa: Arkady 2005.

Rejestr pomników przyrody w województwie dolnośląskim, http://bip.wroclaw.rdos.gov.pl/rejestr-form-ochrony-przyrody. Staffa, M. (1996). Słownik geografii turystycznej Sudetów. T. 13. Góry Stołowe (pp. 236-241). Warszawa: PTTK “Kraj”. Website http://crfop.gdos.gov.pl/CRFOP/search.jsf.

Wydawnictwo Towarzystwa Miłośników Szczytnej „Zabytki Szczytnej” (1985). Szczytna: Biblioteczka Szczytniańska. 


\section{PIESZE SZLAKI TURYSTYCZNE POTENCJAŁEM TURYSTYCZNYM}

\section{MIASTA I GMINY SZCZYTNA}

SŁOWA KLUCZOWE

STRESZCZENIE
Szczytna, turystyka, potencjał turystyczny, piesze szlaki turystyczne, zagospodarowanie turystyczne

W przedstawionych badaniach zwrócono uwagę na potencjał turystyczny miasta i gminy Szczytna, położonych w województwie dolnośląskim, w bliskim sąsiedztwie znanych uzdrowisk Polanica-Zdrój, Duszniki-Zdrój i Kudowa-Zdrój. Szczególną rolę przypisano pieszym szlakom turystycznym, bowiem uznano je jako te, które przyciągają i przyciągać będą turystów i potencjalnych inwestorów. Na terenie miasta i gminy Szczytna występują nieliczne zabytki architektoniczne, zabytkowe elementy małej architektury, ciekawe formy ochrony przyrody: Park Narodowy Gór Stołowych, Torfowisko pod Zieleńcem (rezerwat przyrody), Góry Bystrzyckie i Orlickie (obszar chronionego krajobrazu), obszar Natura 2000, 8 pomników przyrody. Wszystkie te wymienione elementy podziwiać można, przemierzając piesze szlaki turystyczne, których, na terenie gminy Szczytna, jest obecnie około $115 \mathrm{~km}$ długości. W ramach prowadzonych badań przeanalizowano ponad $70 \mathrm{~km}$ tychże. Długość i gęstość szlaków implikuje dużą atrakcyjność badanego obszaru, dlatego poszukiwano miejsc o wysokim potencjale turystycznym. Do zwaloryzowania szlaków turystycznych wybrano Metodę krzywej wrażeń Wejcherta, która pozwoliła na dokonanie ich oceny. Na podstawie jej wyniku wskazano miejsca pod nowe inwestycje turystyczne. 